\title{
Effects of orbital forcing on atmosphere and ocean heat transports in Holocene and Eemian climate simulations with a comprehensive Earth system model
}

\author{
N. Fischer ${ }^{1,2}$ and J. H. Jungclaus ${ }^{1}$ \\ ${ }^{1}$ Max Planck Institute for Meteorology, Hamburg, Germany \\ ${ }^{2}$ International Max Planck Research School for Earth System Modelling, Hamburg, Germany \\ Received: 22 September 2009 - Published in Clim. Past Discuss.: 13 October 2009 \\ Revised: 12 March 2010 - Accepted: 17 March 2010 - Published: 25 March 2010
}

\begin{abstract}
Orbital forcing does not only exert direct insolation effects, but also alters climate indirectly through feedback mechanisms that modify atmosphere and ocean dynamics and meridional heat and moisture transfers. We investigate the regional effects of these changes by detailed analysis of atmosphere and ocean circulation and heat transports in a coupled atmosphere-ocean-sea ice-biosphere general circulation model (ECHAM5/JSBACH/MPI-OM). We perform long term quasi equilibrium simulations under pre-industrial, mid-Holocene (6000 years before present - yBP), and Eemian (125000 yBP) orbital boundary conditions. Compared to pre-industrial climate, Eemian and Holocene temperatures show generally warmer conditions at higher and cooler conditions at lower latitudes. Changes in sea-ice cover, ocean heat transports, and atmospheric circulation patterns lead to pronounced regional heterogeneity. Over Europe, the warming is most pronounced over the north-eastern part in accordance with recent reconstructions for the Holocene. We attribute this warming to enhanced ocean circulation in the Nordic Seas and enhanced oceanatmosphere heat flux over the Barents Shelf in conduction with retreat of sea ice and intensified winter storm tracks over northern Europe.
\end{abstract}

\section{Introduction}

Changes of insolation distribution due to variations in the Earth's orbit around the sun are considered the dominant external forcing of glacial-interglacial cycles throughout the

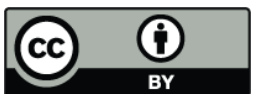

Correspondence to: N. Fischer (nils.fischer@zmaw.de)
Quaternary (the last 2.5 million years) (Milankovic, 1941; Hays et al., 1976; Imbrie et al., 1992). Their impact on the climate of interglacial periods has been studied in previous coupled atmosphere-ocean modeling work mainly focussing on the atmosphere component of the climate system (e.g., Braconnot et al., 2007a,b). Notable exceptions were transient simulations of the Holocene with a coupled Earth system model of intermediate complexity (EMIC) by Renssen et al. (2006) and a Holocene time-slice study with 120-yearlong simulations with a coupled atmosphere-ocean GCM by Liu et al. (2003) who analyzed ocean dynamics. Subject of the present study are effects of orbital forcing on regional climate and the role of orbitally induced changes in atmospheric and oceanic circulation and the associated heat transports in the Holocene (6000 years before present $-\mathrm{yBP}$ ) and the last interglacial period, the Eemian (125000 yBP), compared to pre-industrial climate in a fully coupled atmosphere-oceansea ice-biosphere general circulation model (GCM).

Glacial-interglacial cycles in the Quaternary had a periodicity of approximately 100000 years for the last 500000 years and the interglacial periods lasted for 7000 to 17000 years. The main driver of the cycles is assumed to be summer insolation at high northern latitudes. It increases when the eccentricity of the Earth's orbit around the sun is high, the obliquity of the Earth's axis of rotation is increased and, concurrently, perihelion is close to summer solstice. For the last two interglacial periods insolation maxima at high northern latitudes occurred $9000 \mathrm{yBP}$ in the Holocene and $127000 \mathrm{yBP}$ in the Eemian. Due to the global climate system's inertia, e.g., continental ice sheets and ocean heat content, there is a delay up to several millennia in climate response, thus the climate optimum of the present interglacial, the Holocene, as well as that of the Eemian occurred several millennia after the insolation maximum. During the Eemian,

Published by Copernicus Publications on behalf of the European Geosciences Union. 
the eccentricity of the Earth's orbit around the sun was larger than in the Holocene and therefore insolation changes were more pronounced.

The paleo model intercomparison project PMIP2 (Braconnot et al., 2007a) compared the Holocene climate to pre-industrial climate using data obtained from different GCMs and EMICs. For the Holocene simulations the models showed an increased seasonal cycle in the Northern Hemisphere with annual mean temperatures increasing in the higher latitudes and decreasing in the tropics. Their study concluded that the sea ice-albedo-feedback strengthens the seasonal cycle in the Northern Hemisphere. The study showed that the ocean played a major role in the evolution of past climates, since the results matched proxy reconstructions better than those obtained from the atmosphere only study PMIP (Joussaume and Taylor, 1995) performed earlier. Nevertheless, PMIP2 related publications did not discuss ocean dynamics in detail. Using an atmosphere-ocean GCM, Kaspar et al. (2007) found an increase of Eemian winter storm tracks over the North Atlantic and a decrease over the Pacific. The Atlantic storm tracks experienced a significant northward shift. The changes were attributed to orbitally induced changes in the meridional temperature gradient. With a similar model setup, Groll et al. (2005) investigated the relationship between regional temperatures and large-scale circulation for the Eemian compared to pre-industrial climate. Their simulations showed a decrease in the Arctic Oscillation temperature signal (the correlation between sea-level pressure anomalies and near surface temperature) due to lower simulated winter temperature in the Northern Hemisphere in the Eemian but similar circulation variability.

An analysis of ocean dynamics in the Holocene was performed by Renssen et al. (2006) in a transient simulation of the Holocene from 9000 yBP to today in a coupled atmosphere-sea ice-ocean-vegetation EMIC. The large-scale features of the differences in Holocene climate compared to pre-industrial were similar to those in PMIP2 and the authors proposed geophysical mechanisms concerning changes in the ocean. Deep-water formation in the Atlantic changed due to changed sea-ice cover and ocean-sea ice interaction. In their model study on Holocene climate, Liu et al. (2003) found a symmetric annual mean temperature response of the ocean surface to orbital forcing in both hemispheres, a cooling at low and a warming at high latitudes. Whereas the thermocline response was dominated by an asymmetric pattern with cooling in the northern and warming in the Southern Hemisphere mid-latitudes determined mainly by local winter insolation through surface water subduction.

Three of the five coupled GCM studies however, had to apply heat and/or freshwater flux correction between the atmosphere and ocean model in order to obtain a stable climate. The EMIC applied in Renssen et al. that applied fresh water flux correction only and the model used by Liu et al. (2003) did not use flux correction, but analyzed comparably short simulations (120 years). The flux correction fields were ob- tained under pre-industrial boundary conditions and for the heat flux exceed changes induced by orbital forcing. Therefore the ocean state is "fixed" to a pre-industrial state and thus the effects of orbital forcing on the state of the ocean are superposed.

Reconstructions from paleo proxies revealed differing surface temperature trends in northern Europe and the Nordic Seas on regional scales over the ocean (Hald et al., 2007) as well as over land (Davis et al., 2003) and showed that the warming over north-eastern Europe and Scandinavia is the most pronounced signal.

In a study applying the same model setup as in the present one, Otto et al. (2009) investigated the contributions of the different components of the climate system, atmosphere, ocean and vegetation, to changes in surface temperature in the Holocene. They find that the ocean, the atmosphere and interactions between the two are the main contributors and that vegetation related feedbacks only play a minor role.

In this study, we apply a GCM setup without flux correction to explain the regional patterns of climate change. We perform detailed analysis of changes in the ocean circulation and heat transports and investigate their effects on regional climate in conjunction with changes in the state of the atmosphere. We present results obtained from two time-slice simulations with a comprehensive GCM compared to a control run under pre-industrial conditions: one of Holocene climate, $6000 \mathrm{yBP}$, and one of Eemian climate, $125000 \mathrm{yBP}$.

\section{Model and experimental setup}

\subsection{Model setup}

The climate simulations are performed using the MaxPlanck-Institute for Meteorology coupled climate model. The model consists of the spectral atmosphere model ECHAM5 (Roeckner et al., 2003) run at truncation T31, corresponding to a horizontal resolution of a $3.75^{\circ} \times 3.75^{\circ}$ longitude-latitude grid with 19 vertical hybrid sigma pressure levels with the highest level at $10 \mathrm{hPa}$. Integrated in the atmosphere model is the land surface model JSBACH (Raddatz et al., 2007) with a dynamic vegetation module (Brovkin et al., 2009). ECHAM5 is coupled to the general circulation ocean model MPIOM (Marsland et al., 2003) in resolution GR30 with 40 vertical levels (30 levels within the top $2000 \mathrm{~m}$ ) and an included Hibler-type dynamicthermodynamic sea ice model with viscous-plastic rheology (Hibler, 1979).

The ocean model uses a bipolar orthogonal spherical coordinate system and is based on an Arakawa C-grid and allows for an arbitrary placement of the poles. In the setup applied here, the North Pole is shifted over Greenland to avoid numerical singularities combined with the advantage of relatively high resolution in the deep-water formation regions, around Greenland maintaining isotropic conditions. 
The model's South Pole is located at the center of Antarctica also resulting in increased resolution of the deep-water formation regions around Antarctica. The horizontal grid spacing varies between $30 \mathrm{~km}$ around Greenland to $368 \mathrm{~km}$ in the tropical Pacific.

The coupling between the atmosphere and the ocean model is performed by the OASIS coupler (Valcke et al., 2003). Fluxes of momentum, heat, and freshwater from the atmosphere to the ocean are transfered and interpolated onto the ocean grid. From the ocean to the atmosphere sea surface temperature, sea ice thickness and fraction, snow cover on sea ice, and surface velocities are transmitted.

The model includes a river run-off scheme (Hagemann and Dumenil, 1998; Hagemann and Gates, 2003) where river runoff is transferred to the ocean together with the difference in precipitation and evaporation. Mass balance for glaciers and ice-sheets is not accounted for, since snow falling on Antarctica and Greenland is transferred to the nearest ocean grid cell instantaneously. The coupled model runs without flux correction (Jungclaus et al., 2006) and therefore allows for a more realistic representation of oceanic heat transports than flux-corrected models. The time-step is $20 \mathrm{~min}$ for the atmosphere and $2.4 \mathrm{~h}$ for the ocean model components. The coupling time-step between the atmosphere and ocean model is $24 \mathrm{~h}$.

\subsection{Experimental setup}

We run three time-slice simulations for each climatic period under investigation. The respective orbital parameters of the Earth are calculated after Berger (1978) for the Eemian (125000 yBP), the Holocene (6000 yBP) and a pre-industrial control climate (1200 yBP). The latter is chosen such that no anthropogenic influences such as changes in greenhouse gas concentration, etc., need to be considered. Greenhouse gas concentrations are set to pre-industrial values in all three simulations $\left(\mathrm{CO}_{2}\right.$ to $280 \mathrm{ppm}, \mathrm{CH}_{4}$ to $700 \mathrm{ppb}, \mathrm{N}_{2} \mathrm{O}$ to $\left.265 \mathrm{ppb}\right)$. The solar constant is also unaltered in all three experiments since corresponding changes in insolation are small compared to changes induced by changing orbital parameters. In the Holocene simulation, the continental ice sheets and sea level are assumed to be similar to today's. Due to sparse information and better comparability the same continental ice sheets are prescribed in the Eemian simulation. Land surface changes are accounted for by the dynamic vegetation module. Changes in atmospheric dust loads due to volcanic eruptions are not taken into account. The pre-industrial control simulation was initialized by Levitus and Isayev (1992) climatology for the ocean.

The Holocene and the Eemian simulations start after 2500 years of integration of the pre-industrial control run by changing the orbital parameters accordingly. The control run was assumed to be in equilibrium with the pre-industrial boundary conditions. Both paleo-simulations are integrated for further 1800 years without acceleration or asynchronous coupling of the atmosphere and ocean component. Only the last 1000 years are taken into account in the following analysis assuming that the atmosphere, vegetation and the upper and middle ocean are in equilibrium with the new boundary conditions. In all three experiments, the drift of global ocean temperature at $2200 \mathrm{~m}$ over the investigated simulation period is $0.05 \mathrm{~K}$, global salinity at $2200 \mathrm{~m}$ does not show a trend.

\section{Results}

Altered insolation distribution due to changes in orbital boundary conditions leads to an enhanced seasonal cycle in both the Holocene and the Eemian simulation because the obliquity is increased and summer solstice is closer to perihelion than under pre-industrial conditions. Hence, the qualitative changes with respect to pre-industrial climate are similar in both simulations. Since eccentricity is increased and summer solstice is closer to perihelion in the Eemian simulation, the changes in the seasonal cycle are more pronounced than in the Holocene simulation.

\subsection{Large scale features of mean climate}

During the Holocene and the Eemian, reduced insolation in the summer months compared to pre-industrial conditions at low latitudes leads to lower temperatures in the tropics and sub-tropics especially over the Sahel region, India, and south-east Asia (Fig. 1a). Higher temperatures occur at high latitudes, where summer insolation is increased. The largest increase occurs in the Arctic region (Fig. 2) over the Barents Shelf ( $3 \mathrm{~K}$ in the Holocene, $7 \mathrm{~K}$ in the Eemian) and along the east coast of Greenland ( $3 \mathrm{~K}$ in the Holocene, $4 \mathrm{~K}$ in the Eemian). The Southern Ocean experiences an increase in temperature of $1-2 \mathrm{~K}(2-3 \mathrm{~K}$ in the Eemian) and Antarctica of about $0.5 \mathrm{~K}$ in the Holocene ( $1 \mathrm{~K}$ in the Eemian). In the North Atlantic, temperatures south of Iceland are decreasing by up to $1 \mathrm{~K}$ in the Eemian simulation.

We attribute the temperature decrease in the tropics to an intensification of the African monsoon system. With increased cloud cover over the Sahel region shielding the land surface from direct insolation. Sensible heat flux from the land surface to the atmosphere is thus reduced by up to $30 \mathrm{~W} / \mathrm{m}^{2}$ and $60 \mathrm{~W} / \mathrm{m}^{2}$ in the Holocene and Eemian, respectively, whereas latent heat flux increases by similar amounts. The hydrological cycle is further increased by an increase in vegetation cover. The subsequent decrease in surface albedo (see below), however, is not counterbalancing the cooling effect. The temperature increase in the Arctic is due to a reduction in sea-ice cover in the Arctic and changes in atmospheric and oceanic circulations and heat transports which will be discussed in further detail in the following sub-sections.

Changes in precipitation in the Holocene and the Eemian (Fig. 1b) are qualitatively similar but more enhanced in the 

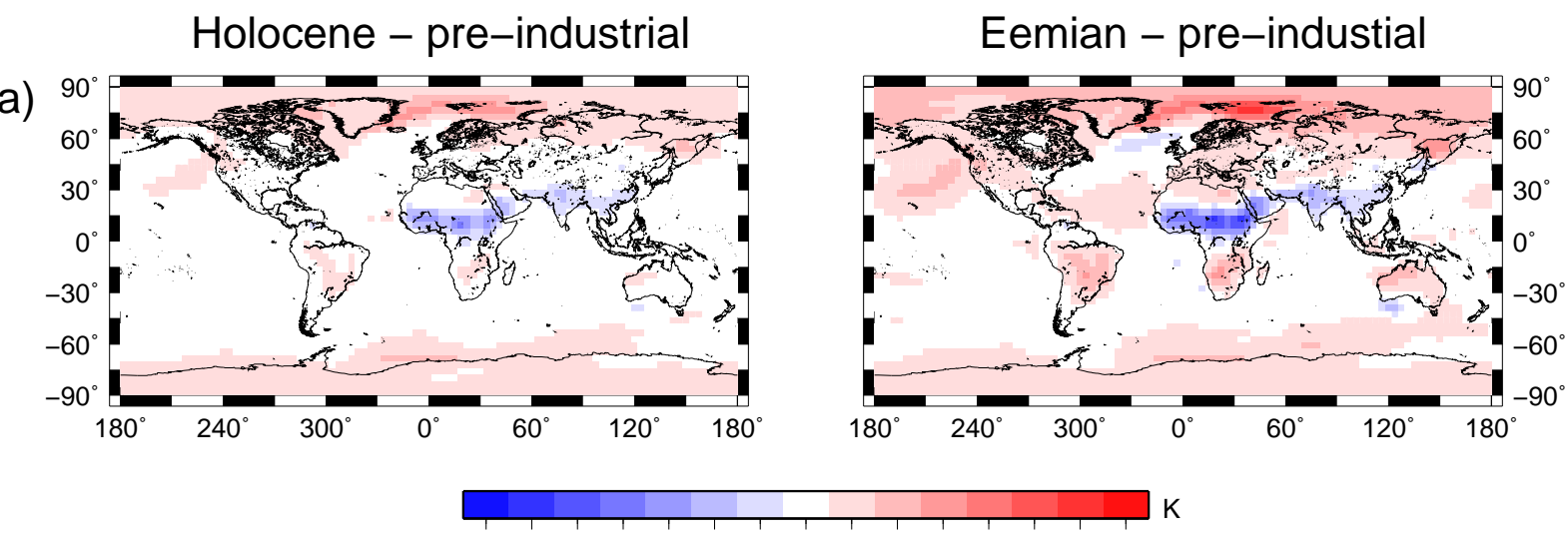

$\begin{array}{lllllllllllllll}-7 & -6 & -5 & -4 & -3 & -2 & -1 & 0 & 1 & 2 & 3 & 4 & 5 & 6 & 7\end{array}$

b)
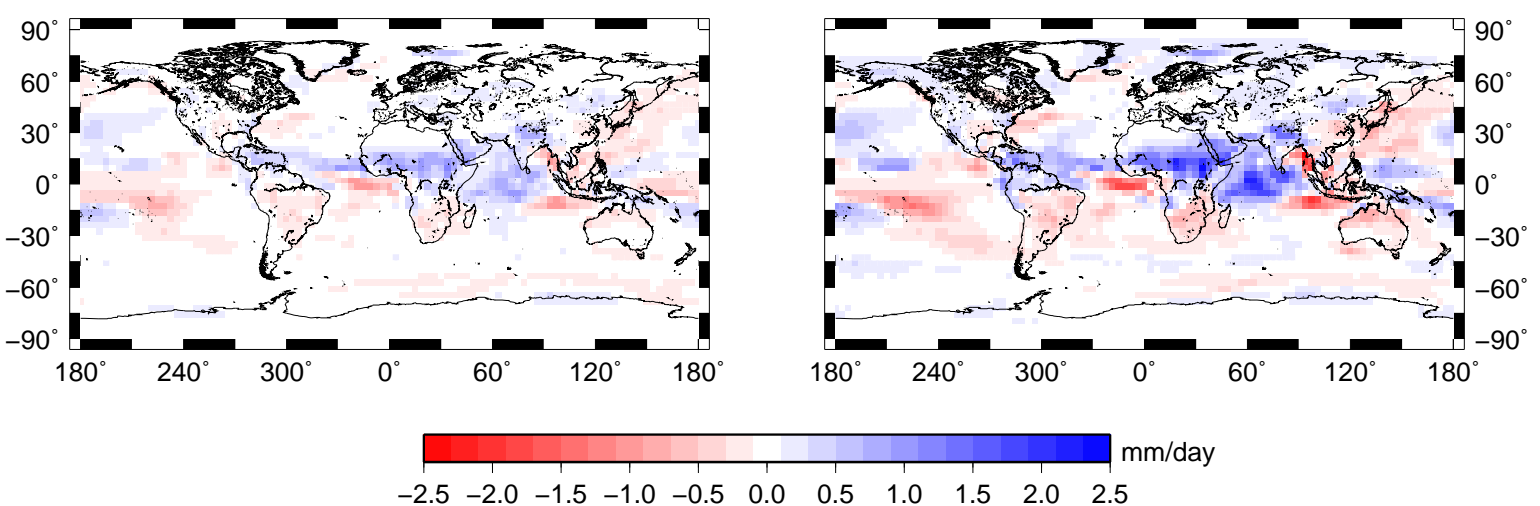

c)
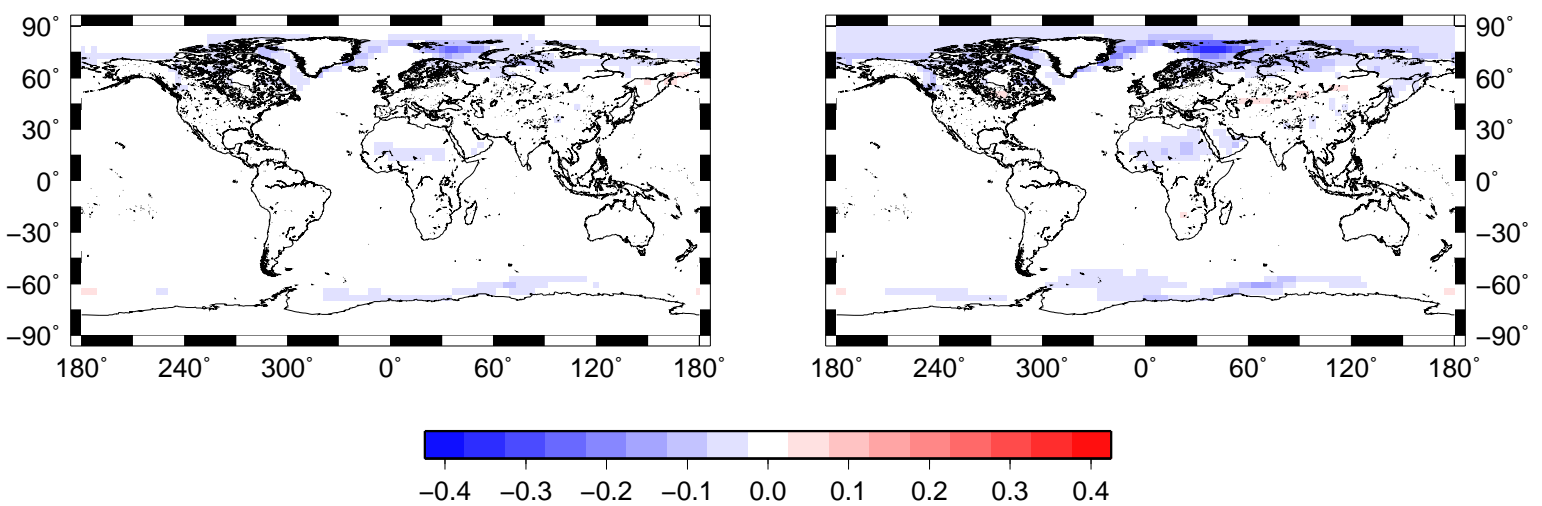

Fig. 1. 1000 year mean differences of Holocene (left) and Eemian (right) minus pre-industrial: (a) near surface temperature (2m-temperature) in $\mathrm{K}$, (b) precipitation in $\mathrm{mm} /$ day (c) surface albedo.

Eemian simulation, with the strongest increase of up to $2.5 \mathrm{~mm}$ per day over the Sahel region and the western Indian ocean. Over the Sahel, this increase is due to similar increases in advective and convective precipitation, whereas over the Indian Ocean, the increase is only seen in convective precipitation. The latitudinal precipitation maximum over the region between $10^{\circ} \mathrm{S}$ and the Equator reduces in the Eemian simulation (though not significantly) by $0.2 \mathrm{~mm} /$ day to $6.0 \mathrm{~mm} /$ day. The latitudinal band between $15^{\circ} \mathrm{N}$ and $30^{\circ} \mathrm{N}$ with no precipitation (over the Sahel region) narrows in the Holocene simulation to $20^{\circ} \mathrm{N}$ and $30^{\circ} \mathrm{N}$ and has almost vanished to a small band around $30^{\circ} \mathrm{N}$ in the Eemian simulation. The strongest decrease of $2.5 \mathrm{~mm} /$ day occurs over the eastern equatorial Atlantic and over the eastern Indian Ocean near Indochina and south of Indonesia. Over the Northern Hemisphere continents at low latitudes, there is a slight increase in precipitation whereas Southern Hemisphere's continents experience a slight decrease. Although a thorough investigation of the monsoon systems is beyond the scope of this study, this could be an indication of a 

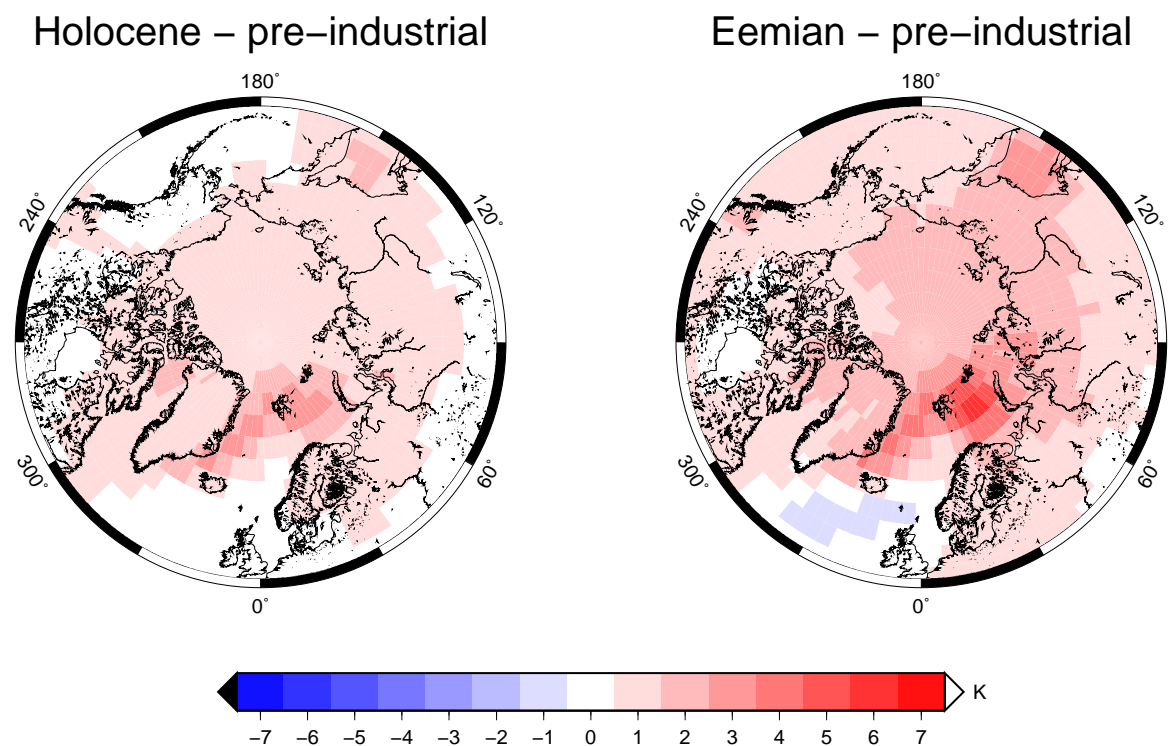

Fig. 2. Temperature changes (in $\mathrm{K}$ ) in the Arctic region for the Holocene and the Eemian compared to pre-industrial climate.

shift in the inter-tropical convergence zone, ITCZ. Following the definition of the ITCZ location given in Braconnot et al. (2008), we observe northward shift over Africa of $1.5^{\circ}\left(3^{\circ}\right)$ over western and central Africa to $9^{\circ}\left(10^{\circ}\right)$ over eastern Africa in the Holocene (Eemian) simulation compared to the pre-industrial one (not shown). Precipitation is increasing in the Arctic with the strongest signal over the Barents Shelf (1 mm/day). Over the Pacific Ocean, precipitation is decreasing in the eastern part of the Northern Hemisphere and over the central part of the Southern Hemisphere. In the southwestern Pacific there is an increase in precipitation east of the Philipines and south-east of New Guinea. Most parts of Antarctica experience changes in precipitation below $10 \%$. Albeit the increase of $1 \mathrm{~K}$ in temperature very dry conditions with precipitation well below $1 \mathrm{~mm} /$ day prevail.

Surface albedo (Fig. 1c) is reduced in the Sahel in the Holocene and the Eemian owing to an increase in vegetation cover and in the Arctic due to reduction in sea ice cover especially over the Barents Shelf and on the East coast of Greenland. Because of a decrease in snow cover and a northward shift in the boreal tree line, surface albedo is reduced in most parts of northern Siberia, Scandinavia, and northern North America.

\subsection{Atmospheric heat transports and circulation}

We calculate components of meridional advective atmospheric heat transport after Keith (1995). Total advective meridional atmospheric heat transport (htra) is defined as:

htra $=\int\left(c_{p} T+g z+L q\right) v \frac{\mathrm{d} p}{g} \mathrm{~d} x \mathrm{~d} z$ with $c_{p}$ the specific heat capacity of dry air, $T$ temperature, $L$ latent heat of condensation, $q$ water vapor content, $g$ gravitational acceleration, $v$ wind velocity, $p$ pressure and $x$ and $z$ the zonal and vertical coordinate respectively. The integration is performed in the vertical and zonal dimension. The sum of the first two terms is the dry static energy (sensible heat) and the third the moist energy (latent heat). The dry and moist contributions are then split up in three components each: 1) mean meridional, i.e., mean velocity and mean energy, 2) transient eddies, i.e., time anomalies of velocity and energy from the zonal mean, and 3) stationary eddies, i.e., spatial anomalies of velocity and energy from the time and zonal mean.

The zonal integral of heat transport over a hundred year mean of pre-industrial climate shows a similar distribution as the ECMWF analysis from present day data in Keith (1995) (not shown). Total advective heat transport is nearly symmetric in both hemispheres with maxima of $5 \mathrm{PW}$ at $45^{\circ} \mathrm{N}$ and $35^{\circ} \mathrm{S}$ respectively. Mean meridional circulation and stationary eddies contribute about $2 \mathrm{PW}$ each at low latitudes (up to $25^{\circ} \mathrm{N} / 25^{\circ} \mathrm{S}$ ), at latitudes from $30^{\circ}$ to $60^{\circ}$ transient eddies contribute $4 \mathrm{PW}$ in the Northern Hemisphere and $6 \mathrm{PW}$ in the Southern Hemisphere of which 2 PW are compensated for by mean meridional circulation transport associated with the Ferrel Cell.

Comparing the heat transports in the pre-industrial simulation and the Holocene and Eemian simulation (Fig. 3), the total advective heat transport to the Northern Hemisphere decreases up to $0.15 \mathrm{PW}(5 \%)$ and $0.35 \mathrm{PW}(12 \%)$ for the Holocene and the Eemian respectively at $20^{\circ} \mathrm{N}$. The differences in dry and moist components heat transport tend to compensate each other since they are both related to the 

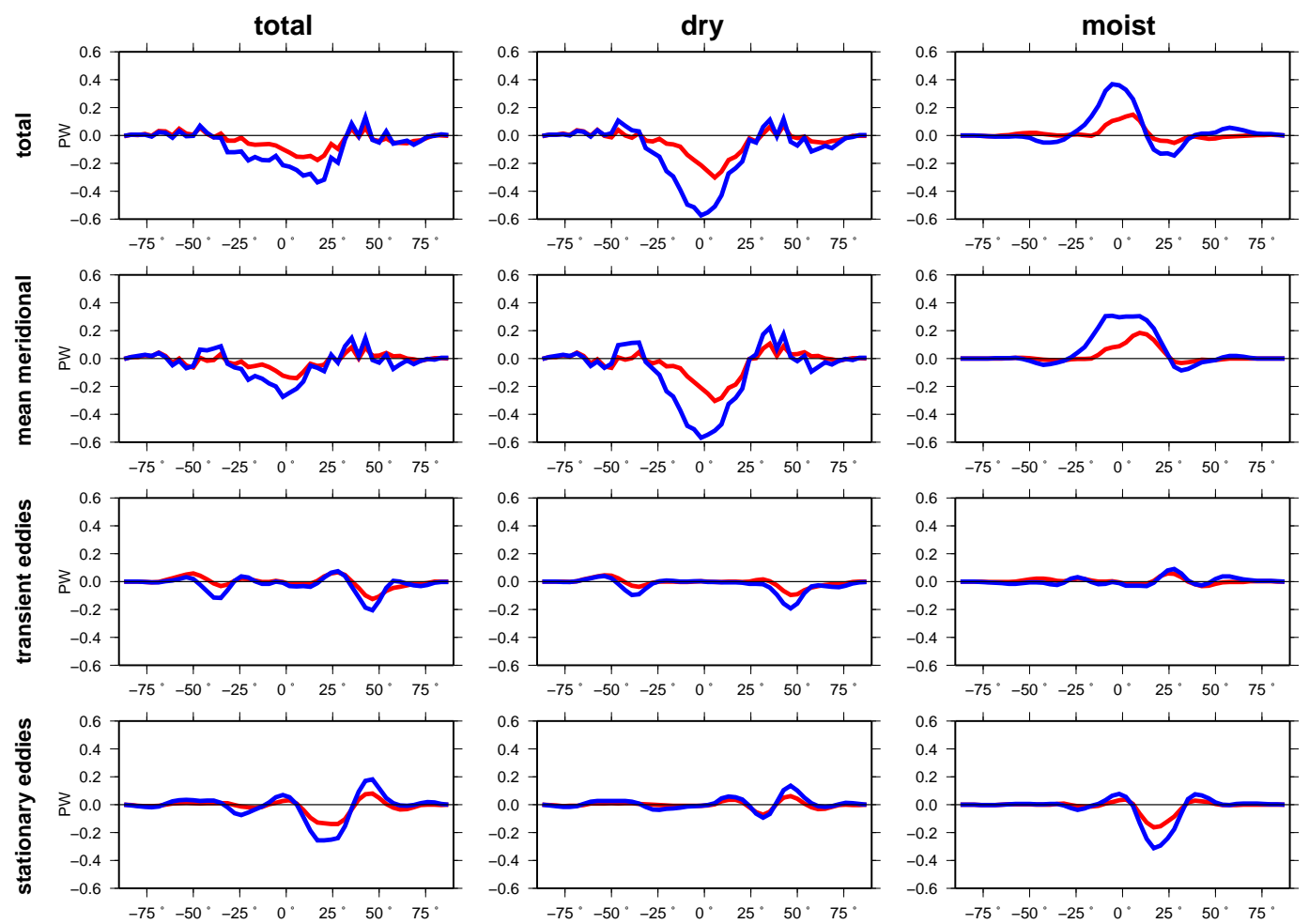

Fig. 3. Differences zonally integrated atmospheric heat transports (in PW - $10^{15} \mathrm{~W}$ ) averaged over 100 years (red line: Holocene - preindustrial; blue line - Eemian - pre-industrial) total (left column), dry or sensible heat (middle column) and moist or latent heat (right column) contributions. In the horizontal the rows show total, mean meridional, transient eddy and stationary eddy contributions from top to bottom.

Hadley circulation where the upper branch transports sensible heat to the poles (positive sign) and the lower branch transports latent heat to lower latitudes (negative sign). A reduction in the strength of the Hadley Cell in the Holocene and the Eemian simulation thus leads to a decrease in sensible heat transport to the poles and an effective increase in latent heat transport to the poles. From $30^{\circ} \mathrm{N}$ to $45^{\circ} \mathrm{N}$ there is a slight increase of $0.05 \mathrm{PW}$ (Holocene) and 0.1 PW (Eemian) compared to the total of around $5 \mathrm{PW}$ due to increasing mean meridional circulation. At mid- to high-northern latitudes there is a reduction in atmospheric heat transport due to reduced heat transport contribution by transient eddies which cannot be completely compensated for by an increase in stationary eddy heat transport at the same latitude region. Significance has been tested by comparing the changes computed from the total advective heat transport to changes computed from the total implied heat transports of the 1000 year investigation period divided in 100 -year-periods. The changes discussed exceed two standard deviations.

To check whether the decrease in transient eddy heat transport is associated with cyclone activity we analyzed Northern Hemisphere winter storm tracks by investigating anomalies in geopotential height at $500 \mathrm{hPa}$ on the synoptic scale, 2.56 days, (Blackmon, 1976) in the three simulations. Figure 4 shows mean geopotential height differences and differences of the calculated storm tracks in the Northern Hemisphere.
The Holocene and the Eemian simulations again show qualitatively similar results with the stronger amplitude in the Eemian simulation. Cyclone activity is reduced over the North Pacific, large parts of Siberia, and the Mediterranean region, whereas it is increased from north-western North America over the North Atlantic through northern and central Europe. The changes in storm tracks are in accordance with changes in the North-Atlantic-Oscillation (NAO) pattern we derived from empirical orthogonal function analysis of North Atlantic sea level pressure anomalies (Hurrell, 1995). There we find an expansion of the high pressure region around the Azores Islands into the Bay of Biscay and parts of western France in the Holocene and more pronounced in the Eemian. The low pressure region that is centered over the southern tip of Greenland in our model remains constant in all three simulations. The increase of the high pressure region leads to a northward shift of the zero-line in the pressure dipole of the high and the low pressure regions. Assuming that most storm tracks pass the dipole along the zero line this shift corresponds to the northward shift of the North Atlantic storm tracks. The NAO-index exhibits decreasing amplitudes in the negative NAO-phases which is connected to the decrease in storm track activity in southern Europe and the Mediterranean region. 

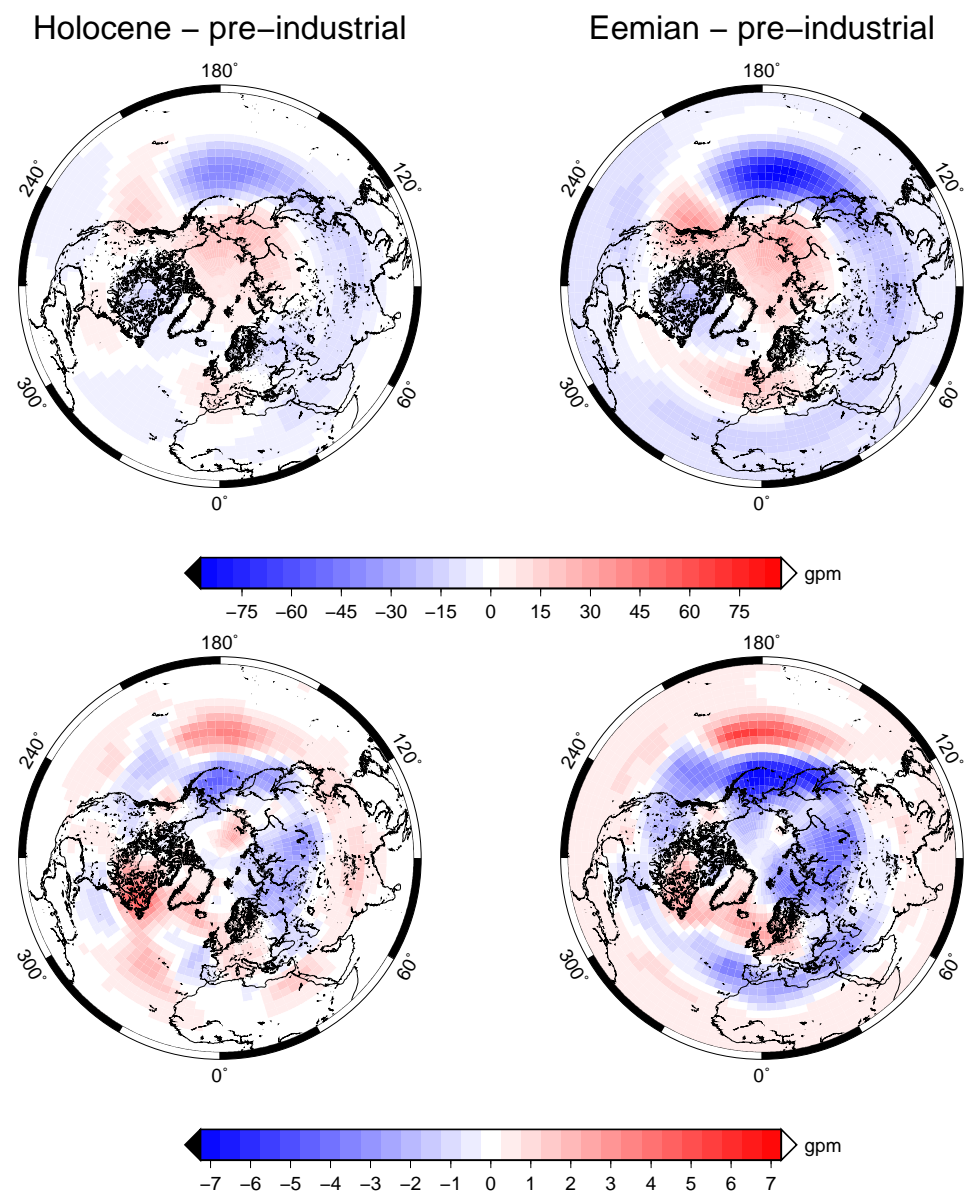

Fig. 4. Northern Hemisphere differences in mean winter geopotential height in gpm (upper row) and winter storm tracks, defined as synopticscale geopotential height anomalies at $500 \mathrm{hPa}$ in gpm (lower row).

\subsection{Sea ice}

In the Holocene and the Eemian simulation, sea-ice cover in the Arctic is reduced compared to pre-industrial (Fig. 5) especially in the summer months where the insolation in high northern latitudes increases by up to $40 \mathrm{~W} / \mathrm{m}^{2}$ in the Holocene and $65 \mathrm{~W} / \mathrm{m}^{2}$ in the Eemian. In the winter months, where in both the Holocene and the Eemian insolation is lower compared to pre-industrial, sea ice is not building up to compensate for the reduction. This leads to an allmost icefree Barents Shelf troughout the year and a retreat of the ice margin along the east coast of Greenland. The corresponding reduction in surface albedo (Fig. 1c) leads to increased ocean heat uptake in summer that reduces sea-ice growth in winter and thus leads to a positive sea ice-albedo feedback. Additionally the lack of sea-ice cover in winter increases the heat flux from the ocean to the atmosphere. Around Antarctica sea-ice thickness is reduced especially in the Wedell Sea up to $1 \mathrm{~m}$ except for an increase in the western Ross Sea up to $0.4 \mathrm{~m}$ (not shown).

\subsection{Oceanic circulation and heat transports}

In the pre-industrial control run, the Atlantic meridional overturning circulation (AMOC), defined as the zonally integrated stream function over the Atlantic basin, has a maximum of $16 \mathrm{~Sv}\left(1 \mathrm{~Sv}=10^{6} \mathrm{~m}^{3} / \mathrm{s}\right)$ at $30^{\circ} \mathrm{N}$ at $1000 \mathrm{~m}$ depth. Antarctic bottom water reaches up to $30^{\circ} \mathrm{N}$ below $3000 \mathrm{~m}$ depth with a strength of $2 \mathrm{~Sv}$. In the Nordic Seas the clockwise circulation cell reaches up to $80^{\circ} \mathrm{N}$ with an intensity of 2 Sv. In the Holocene and the Eemian simulation, the AMOC at latitudes up to $75^{\circ} \mathrm{N}$ reduces to $14 \mathrm{~Sv}$ and $12 \mathrm{~Sv}$, respectively, at its maximum compared to the pre-industrial simulation (Fig. 6). The reduction in AMOC is accompanied by an intensification of Antarctic Bottom Water in the deep ocean of up to $1 \mathrm{~Sv}$ in the Eemian simulation. Both the Eemian and the Holocene simulation show an increase in overturning of up to $1 \mathrm{~Sv}$ compared to the pre-industrial simulation north of $75^{\circ} \mathrm{N}$.

Large scale horizontal circulation in the North Atlantic is expressed in terms of the vertically integrated horizontal barotropic stream function $\left(\psi(x, y)=\iint v d x d z\right.$, with 


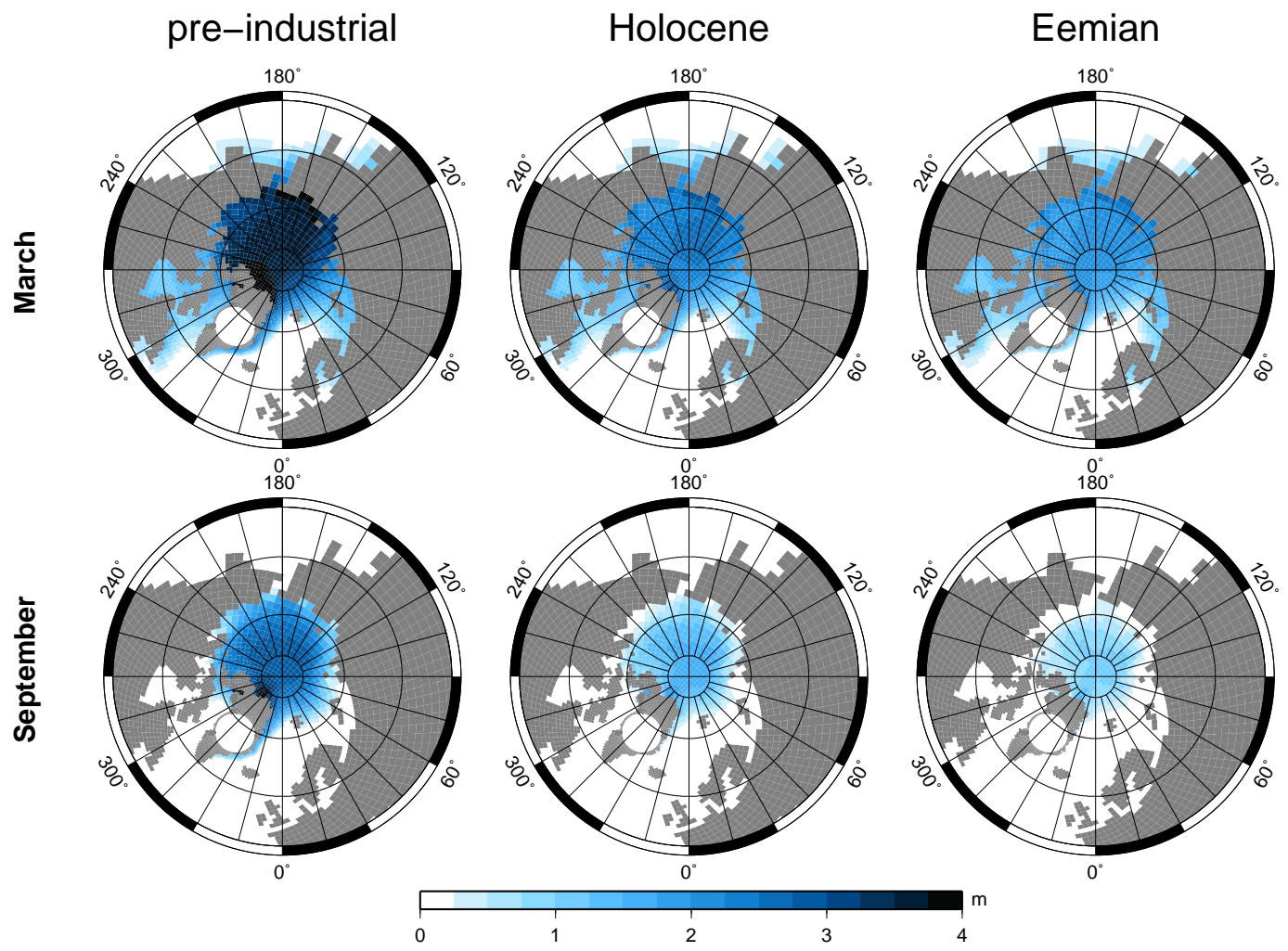

Fig. 5. Sea ice thickness in $\mathrm{m}$ in the Arctic Ocean in pre-industrial, Holocene, and Eemian conditions in March (upper row) and September (lower row).

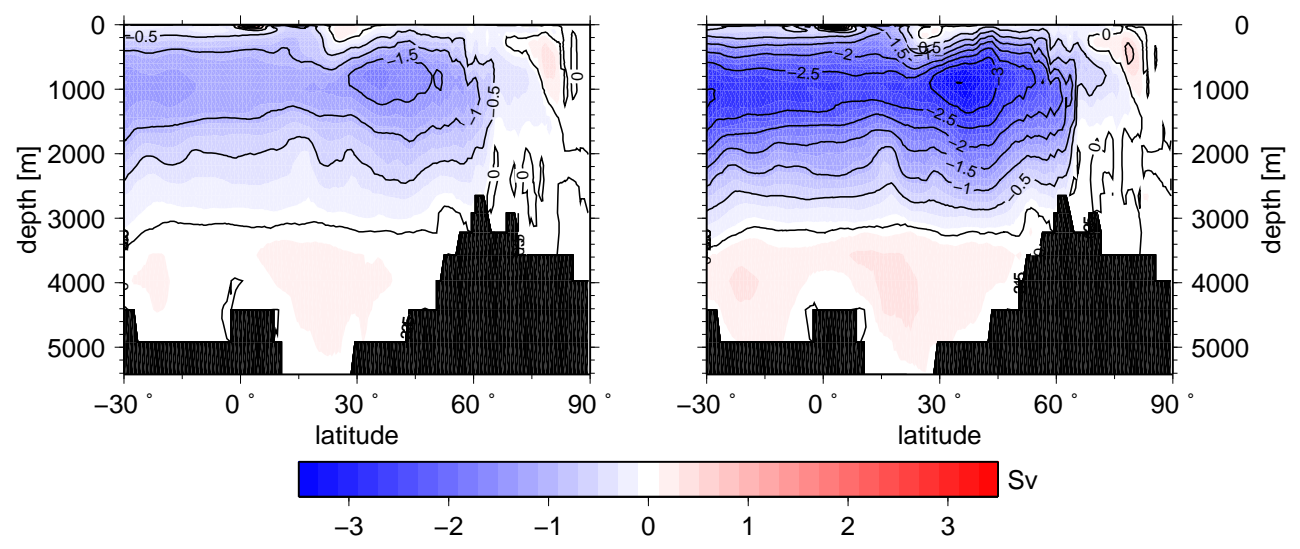

Fig. 6. Differences of the zonally integrated vertical stream function in the North Atlantic in $\mathrm{Sv}\left(10^{6} \mathrm{~m}^{2} / \mathrm{s}\right)$ for (a) Holocene - pre-industrial and (b) Eemian - pre-industrial.

$v$ meridional velocity, $x$ and $z$ the zonal and vertical coordinates). The Nordic Seas gyre maximum intensity increases by up to $1 \mathrm{~Sv}$ in the Holocene simulation and by $1.5 \mathrm{~Sv}$ in the Eemian (pre-industrial maximum: $16 \mathrm{~Sv}$ ) and it expands further north due to the retreat of sea ice and an increasing density gradient with relatively dense water in the center and less dense water at the margins. An investigation of wind stress over the Nordic Seas basin does not show a clear in- fluence on the gyre circulation. Wind stress curl slightly increases along the Norwegian coast, but decreases along the Greenland coast. The sub-polar gyre shows a more diverse signal: the volume transport on the western side of the Reykjanes Ridge southwest of Iceland, which is $35 \mathrm{~Sv}$ in the preindustrial simulation, reduces by $2 \mathrm{~Sv}$ in the Holocene and $4 \mathrm{~Sv}$ in the Eemian, whereas in the deep-water formation region south of the southern tip of Greenland, it is remaining 
at its pre-industrial maximum (48 Sv) in both the Holocene and the Eemian simulation. The sub-tropical gyre weakens by up to $3 \mathrm{~Sv}$ in the south-western part east of the Carribbean in the Holocene and $6 \mathrm{~Sv}$ in the Eemian. The reduction is also affecting the North Atlantic Current which reduces by $2 \mathrm{~Sv}$ in the Holocene and $6 \mathrm{~Sv}$ in the Eemian (pre-industrial maximum at $30^{\circ} \mathrm{W}: 48 \mathrm{~Sv}$ ).

We analyze poleward Atlantic heat transport (htro) defined similarly to atmospheric heat transports:

htro $=c_{p} \int v \theta \mathrm{d} x \mathrm{~d} z$

(Bryan, 1962) where $c_{p}$ is specific heat capacity of water, $v$ meridional velocity, $\theta$ the potential temperature, and $x, z$ the zonal and vertical coordinates. The integration is performed in the vertical and the zonal direction in the margins of the Atlantic basin assuming it to be closed with no net volume transport (with a net volume transport the absolute heat transport value would depend on a reference temperature, set to $0{ }^{\circ} \mathrm{C}$ here). It has been shown in Hall and Bryden (1982) that the transport occurring through Bering Strait (approx. 0.4 Sv in all three model simulations) is negligible and the heat flux estimate thus meaningful. Velocity and potential temperature are split up into a zonal mean and deviations from the zonal mean. Heat transport via AMOC is then defined as the integral of the product of the zonal mean temperature and velocity and heat transport via ocean gyres as the integral of the product of the deviations from zonal mean temperature and velocity.

The poleward oceanic meridional heat transport in the Atlantic at $30^{\circ} \mathrm{N}$ decreases up to $0.08 \mathrm{PW}(-10 \%)$ in the Holocene and $0.12 \mathrm{PW}(-16 \%)$ in the Eemian compared to the pre-industrial simulation (Fig. 7). From $60^{\circ} \mathrm{N}$ to $75^{\circ} \mathrm{N}$ heat transport increases up to $0.02 \mathrm{PW}(+10 \%)$ and $0.03 \mathrm{PW}(+15 \%)$ for the Holocene and the Eemian respectively. Analysis of the contributions of oceanic heat transport from meridional overturning circulation (MOC) and ocean gyres reveals that at $30^{\circ} \mathrm{N}$ MOC (gyre) heat transport changes contribute $0.05 \mathrm{PW}(0.03 \mathrm{PW})$ to the total heat transport decrease in the Holocene and $0.07 \mathrm{PW}(0.05 \mathrm{PW})$ in the Eemian. At high northern latitudes the increase in oceanic heat transport is only due to increased gyre heat transport.

This transport is analyzed in further detail by calculating the volume and heat transports into and out of the Nordic Seas (see Table 1 and Fig. 8 for passages). The total values of the heat transport budget depend on the reference temperature which we choose as the mean temperature of the Nordic Seas basin in the three simulations $\left(T_{\mathrm{ref}}=3.64^{\circ} \mathrm{C}\right)$ and subtracted it from the potential temperature $\left(\theta \rightarrow \theta-T_{\text {ref }}\right)$. Water is transported into the Nordic Seas from the North Atlantic through the Iceland-Scotland-Ridge (ISR) and from the Arctic through Fram Strait (FRAM) and out of the basin through Denmark Strait (DEN) and through the passage between Svalbard and Norway onto the Barents Shelf (BAR). The heat transport is directed as the volume transport in case of ISR and BAR, whereas it has opposite sign for DEN and FRAM. This is due to the fact that the water masses that enter the Nordic Seas through FRAM and leave the basin through DEN have lower temperature than the chosen reference temperature so that the effective heat transport is negative in case of FRAM and positive in case of DEN.

In the Holocene and more enhanced in the Eemian simulation, the volume transports through all passages increase due to enhanced circulation. Nevertheless, this increase in volume transport is not sufficient to explain the changes in heat transport. In case of ISR and BAR, the increase in volume transport has the same sign as the increase in heat transport. In case of the BAR, the relative increase in heat transport is larger then the increase in volume transport. The heat transport increase is also due to an increase of 5\% in heat content of the Nordic Seas basin for the Holocene and the Eemian simulation compared to the pre-industrial. This increase in heat content also contributes to the increase of effective heat transport to the Arctic through FRAM due to the increased temperature difference between the two basins. The temperature difference between the Nordic Seas and the North Atlantic on the other hand decreases and so, despite the increase in volume transport, the effective heat transport into the Nordic Seas via DEN decreases.

The ocean-atmosphere heat flux over the Nordic Seas which is directed from the ocean to the atmosphere in the three simulations reduces only slightly from $178.9 \mathrm{TW}$ $\left(67.5 \mathrm{~W} / \mathrm{m}^{2}\right)$ in the pre-industrial to $176.5 \mathrm{TW}\left(66.6 \mathrm{~W} / \mathrm{m}^{2}\right)$ in the Holocene and $171.5\left(64.7 \mathrm{~W} / \mathrm{m}^{2}\right)$ in the Eemian simulation. Over the Barents Shelf, ocean-atmosphere heat flux increases significantly from $29.4 \mathrm{TW}\left(21.0 \mathrm{~W} / \mathrm{m}^{2}\right)$ in the pre-industrial to $43.0 \mathrm{TW}\left(30.6 \mathrm{~W} / \mathrm{m}^{2}\right)$ in the Holocene and $58.8 \mathrm{TW}\left(41.9 \mathrm{~W} / \mathrm{m}^{2}\right)$ in the Eemian simulation. Over the Nordic Seas, the spatial distribution of ocean-atmosphere heat flux changes such that it increases along the east coast of Greenland where the ice margin has shifted north and decreases over the rest of the basin especially east of Iceland (Fig. 8). In the northern part, where the sea ice along the east coast of Greenland has retracted there is an increase in ocean-atmosphere heat flux of up to $70 \mathrm{~W} / \mathrm{m}^{2}$ (Fig. 8) accompanied by an increase in deep water formation north of $75^{\circ} \mathrm{N}$ (Fig. 6).

\section{Discussion}

Globally we observe higher temperatures at high latitudes and lower temperatures in the tropics and northern subtropics the in the Holocene and the Eemian simulation compared to temperatures in the pre-industrial simulation. This is in accordance with the changes in orbital forcing, i.e., the differences are directly related to differences in insolation. For the Holocene these results agree reasonably well with reconstructions obtained from marine alkenone proxies (Rimbu et al., 2003) as well as with results from the PMIP2 exercise 

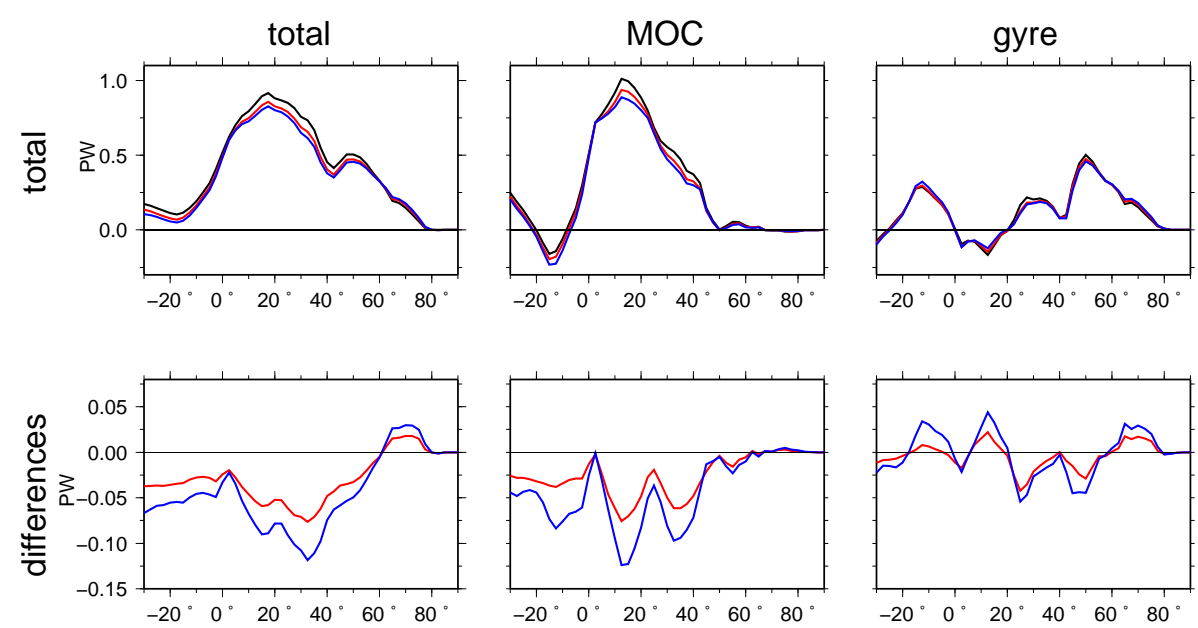

Fig. 7. Upper row: heat transports in PW $\left(10^{15} \mathrm{~W}\right)$ in the Atlantic basin in pre-industrial (black), Holocene (red), and Eemian (blue) simulations, total and contributions to heat transport from meridional overturning circulation and via gyre transport. Lower row: heat transport differences for Holocene - pre-industrial (red) and Eemian - pre-industrial (blue).

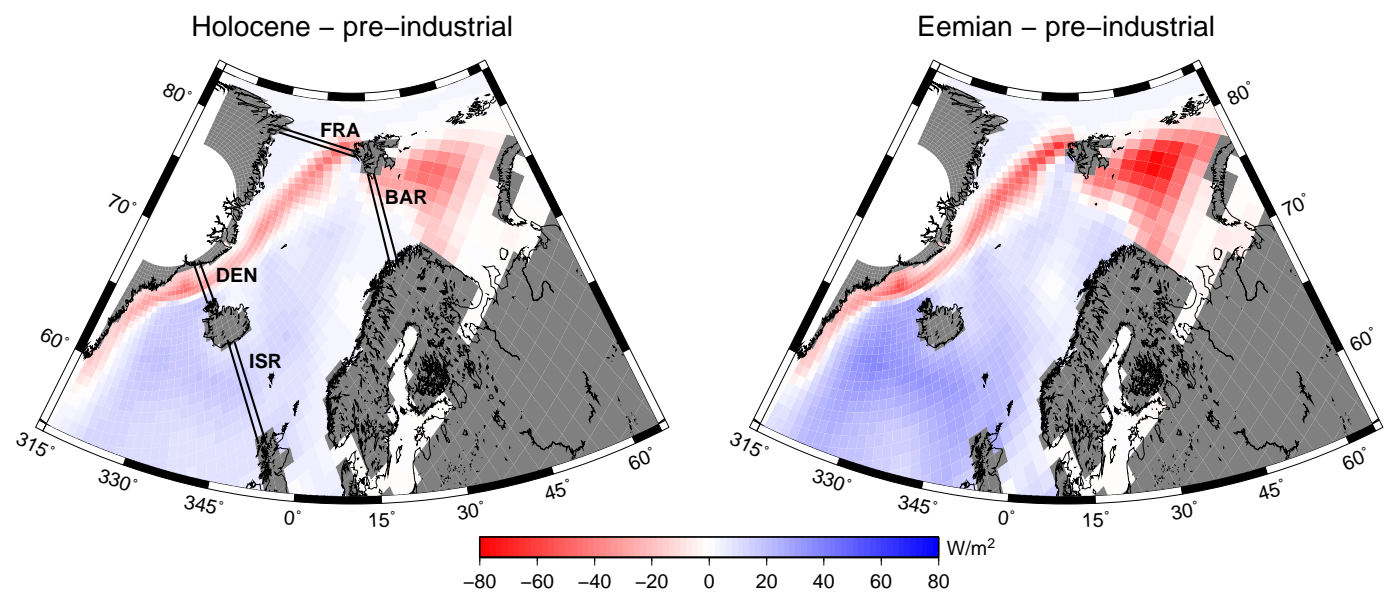

Fig. 8. Ocean-atmosphere heat flux differences in $\mathrm{W} / \mathrm{m}^{2}$ over the Nordic Seas and Barents Shelf. Increases in heat flux from the ocean to the atmosphere (negative sign) occur mainly in regions where sea ice cover is decreased, over the Barents Shelf and on the East coast of Greenland. South of Iceland and in the Eastern part of the Nordic Seas ocean-to-atmosphere heat flux is reduced. The black lines denote the passages used for the calculation of the heat transport in and out of the basin: ISR - Iceland-Scottland-Ridge, DEN - Denmark Strait, BAR - Barents Shelf, FRA - Fram Strait.

(Braconnot et al., 2007a,b) and qualitatively with the results of Liu et al. (2003). Enlarged eccentricity and summer solstice being closer to perihelion in the Eemian simulation lead to more enhanced changes compared to the Holocene simulation. Besides these zonally averaged effects of the orbital forcing feedback mechanisms between the ocean and the atmosphere manifest themselves in particularly enhanced temperature signals in the tropical African monsoon region and in the Nordic Seas.

The intensification of precipitation over the African monsoon region in the Holocene and the Eemian simulation is accompanied by a decrease in mean temperature over land leading to a decrease in land-sea-contrast. Increased precipi- tation in the northern sub-tropics, related to a northward shift of the intertropical convergence zone, ITCZ, also leads to a northward expansion of the Sahel region at the expense of the desert. This increase in vegetation then again enhances the hydrological cycle through increased evaporation (Braconnot et al., 1999, 2008) thus creating a feedback loop. The effect is present in our paleo model simulations but might be underestimated since the dynamic vegetation module is not capable of changing the soil type. In the setup used in this study, the vegetation is shifting but the soil and its albedo is fixed to pre-industrial conditions. A thorough analysis of African and also Indian monsoon dynamics in the atmosphere-ocean GCMs used in PMIP2 has been performed by Zhao et al. 
Table 1. Heat transports (in TW-10 $12 \mathrm{~W}$ ), volume transports (in $\mathrm{Sv}-10^{6} \mathrm{~m}^{2} / \mathrm{s}$ ), and changes in volume transport with respect to the preindustrial transports (in \%) into (pos.) and out of (neg.) the Nordic Seas through the passages depicted in Fig. 8. Increasing negative values for BAR and FRAM indicate increased heat transports into the Arctic.

\begin{tabular}{llrrr}
\hline Section & Transport & PRI & HOL & EEM \\
\hline \multirow{2}{*}{ ISR } & heat & $183.8 \mathrm{TW}$ & $199.8 \mathrm{TW}$ & $213.9 \mathrm{TW}$ \\
& volume & $5.65 \mathrm{~Sv}$ & $6.22 \mathrm{~Sv}(+10 \%)$ & $6.88 \mathrm{~Sv}(+21 \%)$ \\
\multirow{2}{*}{ DEN } & heat & $55.3 \mathrm{TW}$ & $44.2 \mathrm{TW}$ & $38.9 \mathrm{TW}$ \\
& volume & $-6.11 \mathrm{~Sv}$ & $-6.75 \mathrm{~Sv}(+10 \%)$ & $-7.14 \mathrm{~Sv}(+16 \%)$ \\
& heat & $-11.0 \mathrm{TW}$ & $-19.1 \mathrm{TW}$ & $-27.0 \mathrm{TW}$ \\
BAR & volume & $-2.25 \mathrm{~Sv}$ & $-2.68 \mathrm{~Sv}(+19 \%)$ & $-3.10 \mathrm{~Sv}(+38 \%)$ \\
& heat & $-47.8 \mathrm{TW}$ & $-53.0 \mathrm{TW}$ & $-61.2 \mathrm{TW}$ \\
\multirow{2}{*}{ FRAM } & volume & $2.65 \mathrm{~Sv}$ & $2.98 \mathrm{~Sv}(+12 \%)$ & $3.30 \mathrm{~Sv}(+25 \%)$ \\
\hline
\end{tabular}

(2005). They conclude, that the intensification of the African monsoon is mainly due to advective moisture transport from the oceans, probably owing to the fact that the models investigated do not include dynamic vegetation.

In high northern latitudes the increase in summer insolation influences the sea-ice coverage in the Arctic. The sea-ice melt in the summer months due to the increased insolation is enhanced by the sea ice-albedo feedback (Harvey, 1988) and cannot be counterbalanced by sea-ice built-up in winter. In the absence of sea ice over the Barents Shelf and along the east coast of Greenland sea-ice cover cannot act as an insulator between the ocean and the atmosphere. The heat flux from the ocean to the atmosphere increases over the Barents Shelf and shifts further north over the Nordic Seas in the Holocene and the Eemian simulation enhancing the overall warming signal in high northern latitudes counterbalancing the decrease in winter insolation due to the prolonged winter season. The heat is transported by the relatively warm and saline water coming from the North Atlantic over the Iceland-Scotland-Ridge into the Nordic Seas. The volume transport and thus the heat transport consists of vertical overturning circulation and horizontal gyre circulation contributions. The increase in heat transport to high northern latitudes is mainly due to strengthened gyre circulation in the Nordic Seas that is caused baroclinically by an increase in the density gradient and to some extend by an increase in wind stress at the eastern margin of the basin along the Norwegian coast. The strengthening of the gyre is favored by increased convection at its center visible in the local increase in meridional overturning circulation at $75^{\circ} \mathrm{N}$ in the Holocene and the Eemian simulation. Bitz et al. (2006) investigate changes in the ocean in a coupled AO-GCM (CCSM3) under increasing $\mathrm{CO}_{2}$ forcing. They also find increased circulation and thus heat transport in the Arctic region comparable to the changes we find in our paleo-simulations. They attribute this increase to increased convection along the Siberian Shelf. Our findings concerning the enhanced temperature increase in the Barents Shelf region agree with paleo reconstructions of SST (e.g., Hald et al., 2007; Duplessy et al., 2001) for that area in the mid-Holocene, although temperature increase in Duplessy et al. (2001) is dated around 8000-7000 yBP. Reconstructions of surface temperature in Europe (Cheddadi et al., 1996; Davis et al., 2003; Hald et al., 2007) reveal higher temperatures especially in northeastern Europe that could be explained by the heat release from the Barents Sea, but less temperature increase in central and western Europe where the eastern Atlantic is not considerably warmer than at preindustrial conditions. The model simulations, however, do not show a significant decrease in precipitation especially over Scandinavia as suggested by several paleo studies (e.g., Cheddadi et al., 1996; Barnekow, 2000; Antonsson et al., 2008). The coarse spatial resolution might not be able to resolve the heterogeneous pattern seen for example in Wanner et al. (2008). The surface temperature for the Holocene obtained from multi-model ensemble means in PMIP2 (Braconnot et al., 2007a) does not show regional amplifications in the high northern latitude band $\left(70^{\circ} \mathrm{N}\right.$ to $\left.90^{\circ} \mathrm{N}\right)$, but rather a homogeneous signal over the whole Arctic domain with regional differences below $0.5 \mathrm{~K}$. For the Eemian the temporal and spatial resolution of reconstructions of the Barents Sea region is too coarse to compare them to our model results. Since the forcing is similar to the Holocene one but more enhanced and the effects are also similar but more enhanced the proposed mechanism seems to apply too.

The increased winter storm tracks over the North Atlantic and into northern and central Europe and decreased winter storm tracks in the southern North Atlantic and the Mediterranean region in the Holocene and the Eemian simulation agree with results presented by Kaspar et al. (2007), although changes in temperature for winter over North America in their simulations are lower than the ones found in our simulations.

In their study on Eemian European winter temperatures, Kaspar et al. (2005) show that reduced sea-ice cover in winter over the Barents Sea in conjunction with lower average sea level pressure over the North Atlantic and a subsequent 
expansion of Icelandic low leads to stronger westerlies at $60^{\circ} \mathrm{N}$ and increased heat transport from Atlantic into northern Europe. The results on westerlies and heat transport obtained from our experiments are similar except for the expansion of the Icelandic low. A difference is the west-to-east temperature gradient over Europe that changes sign in their simulation, as opposed in our experiment where temperatures over western Europe do not experience strong changes in the Holocene and the Eemian simulations.

The global temperature, precipitation, and albedo changes shown in transient experiments of the Eemian performed with an earlier generation of the model setup used in this study (Schurgers et al., 2007) are in good agreement with the results presented here. The changes in their study of the Eemian period from $127000 \mathrm{yBP}-125000 \mathrm{yBP}$ are larger than in this study where we only consider a timeslice at 125000 yBP conditions because of the initial conditions of their transient experiment that were obtained from a equilibrium experiment run under orbital forcing corresponding to the insolation maximum in the Eemian which was at $127000 \mathrm{yBP}$ and declined thereafter, not taking into account melting continental ice sheets, etc. of the preceding glacial period.

The results obtained in this study using a general circulation Earth system model agree with climate data reconstructed from paleo proxies in the Nordic Seas (e.g., Rimbu et al., 2003) but disagree with proxy data in the eastern North Atlantic that show lower temperatures on the western coast of Europe off Portugal and northern Africa off Morocco (Rimbu et al., 2004; Lorenz et al., 2006). This might be related to the models representation of the North Atlantic current that is flowing in a east-west direction rather than a southwest to northeast direction thus transporting heat to the eastern North Atlantic.

For the Eemian simulation the comparison with proxy data is even more complicated, since the distribution of continental ice sheets in the Northern Hemisphere and their deglaciation is still under debate (e.g., Bauch and Erlenkeuser, 2008). The subsequent freshwater inputs into the ocean which alter the ocean circulation and the climatic response are not considered in this study. The results presented here are rather an account of changes induced by orbital forcing only.

\section{Conclusions}

Changes in mean temperature induced by changed orbital parameters are regionally enhanced through feedback mechanisms in the climate system. These mechanisms involve changes in atmosphere and ocean circulation and changes induced by the interaction of the two components of the Earth system. The temperature in the Arctic in the Holocene and the Eemian simulation is higher not only in summer but through the whole year due to increased oceanic heat transport in high northern latitudes and reduced sea-ice cover.
Heat is released to the atmosphere over the Nordic Seas and, in particular, the Barents Sea. The increase in temperature over Europe is then more enhanced in the north-eastern part of the continent than in the central and western part. Changes in atmospheric circulation in the Northern Hemisphere lead to a reduction of storm tracks over the Mediterranean region especially in the Eemian and an increase of storm tracks over the northern North Atlantic over Iceland into northern and central Europe.

Acknowledgements. This work has been performed within the priority program INTERDYNAMIK of the German Research Foundation (DFG). The model experiments were carried out on the supercomuting system of the German Climate Computation Centre (DKRZ) Hamburg. The authors would like to thank Uwe Mikolajewicz and two anonymous referees for helping to improve the manuscript.

The service charges for this open access publication have been covered by the Max Planck Society.

Edited by: P. Braconnot

\section{References}

Antonsson, K., Chen, D., and Seppä, H.: Anticyclonic atmospheric circulation as an analogue for the warm and dry mid-Holocene summer climate in central Scandinavia, Clim. Past, 4, 215-224, 2008 ,

http://www.clim-past.net/4/215/2008/.

Barnekow, L.: Holocene regional and local vegetation history and lake-level changes in the Torneträsk area, northern Sweden, J. Paleolimnol., 23, 343-456, 2000.

Bauch, H. A. and Erlenkeuser, H.: A critical climatic evaluation of last interglacial (MIS 5e) records from the Norwegian Sea, Polar Res., 27, 135-151, 2008.

Berger, A.: Long-Term Variations Of Daily Insolation And Quaternary Climatic Changes, J. Atmos. Sci., 35, 2362-2367, 1978.

Bitz, C., Gent, P., Woodgate, R., Holland, M., and Lindsay, R.: The influence of sea ice on ocean heat uptake in response to increasing $\mathrm{CO}_{2}$, J. Climate, 19(11), 2437-2450, 2006.

Blackmon, M.: Climatological spectral study of $500 \mathrm{mb}$ geopotential height of northern hemisphere, J. Atmos. Sci., 33, 16071623, 1976.

Braconnot, P., Joussaume, S., Marti, O., and de Noblet, N.: Synergetic feedbacks from ocean and vegetation on the African monsoon response to mid-Holocene insolation, Geophys. Res. Lett., 26, 2481-2484, 1999.

Braconnot, P., Otto-Bliesner, B., Harrison, S., Joussaume, S., Peterchmitt, J.-Y., Abe-Ouchi, A., Crucifix, M., Driesschaert, E., Fichefet, Th., Hewitt, C. D., Kageyama, M., Kitoh, A., Laîné, A., Loutre, M.-F., Marti, O., Merkel, U., Ramstein, G., Valdes, P., Weber, S. L., Yu, Y., and Zhao, Y.: Results of PMIP2 coupled simulations of the Mid-Holocene and Last Glacial Maximum Part 1: experiments and large-scale features, Clim. Past, 3, 261277, 2007a.

Braconnot, P., Otto-Bliesner, B., Harrison, S., Joussaume, S., Peterchmitt, J.-Y., Abe-Ouchi, A., Crucifix, M., Driesschaert, E., 
Fichefet, Th., Hewitt, C. D., Kageyama, M., Kitoh, A., Loutre, M.-F., Marti, O., Merkel, U., Ramstein, G., Valdes, P., Weber, L., Yu, Y., and Zhao, Y.: Results of PMIP2 coupled simulations of the Mid-Holocene and Last Glacial Maximum - Part 2: feedbacks with emphasis on the location of the ITCZ and mid- and high latitudes heat budget, Clim. Past, 3, 279-296, $2007 \mathrm{~b}$.

Braconnot, P., Marzin, C., Grégoire, L., Mosquet, E., and Marti, O.: Monsoon response to changes in Earth's orbital parameters: comparisons between simulations of the Eemian and of the Holocene, Clim. Past, 4, 281-294, 2008,

http://www.clim-past.net/4/281/2008/.

Brovkin, V., Raddatz, T., Reick, C. H., Claussen, M., and Gayler, V.: Global biogeophysical interactions between forest and climate, Geophys. Res. Lett., 36, L07405, doi:10.1029/2009GL037543, 2009.

Bryan, K.: Measurements of Meridional Heat Transport by Ocean Currents, J. Geophys. Res., 67, 3403-3414, 1962.

Cheddadi, R., Yu, G., Guiot, J., Harrison, S., and Prentice, I.: The climate of Europe 6000 years ago, Climate Dynam., 13(1), 1-9, 1996.

Davis, B. A. S., Brewer, S., Stevenson, A. C., Guiot, J., and Contributors, D.: The temperature of Europe during the Holocene reconstructed from pollen data, Quaternary Sci. Rev., 22, 17011716, 2003.

Duplessy, J.-C., Ivanova, E., Murdmaa, I., Paterne, M., and Labeyrie, L.: Holocene paleoceanography of the northern Barents Sea and variations of the northward heat transport by the Atlantic Ocean, Boreas, 30, 2-16, 2001.

Groll, N., Widmann, M., Jones, J., Kaspar, F., and Lorenz, S.: Simulated relationships between regional temperatures and large-scale circulation: $125 \mathrm{kyr} \mathrm{BP}$ (Eemian) and the preindustrial period, J. Climate, 18, 4032-4045, 2005.

Hagemann, S. and Dumenil, L.: A parametrization of the lateral waterflow for the global scale, Clim. Dynam., 14, 17-31, 1998.

Hagemann, S. and Gates, L.: Improving a subgrid runoff parameterization scheme for climate models by the use of high resolution data derived from satellite observations, Clim. Dynam., 21, 349359, doi:10.1007/s00382-003-0349-x, 2003.

Hald, M., Andersson, C., Ebbesen, H., Jansen, E., KlitgaardKristensen, D., Risebrobakken, B., Salomonsen, G., Sarnthein, M., Sejrup, H. P., and Telford, R. J.: Variations in temperature and extent of Atlantic Water in the northern North Atlantic during the Holocene, Quaternary Sci. Rev., 26, 3423-3444, 2007.

Hall, M. M. and Bryden, H. L.: Direct estimates and mechanisms of ocean heat transport, Deep Sea Res., 29(3A), 339-359, 1982.

Harvey, L. D. D.: On The Role Of High-Latitude Ice, Snow, And Vegetation Feedbacks In The Climatic Response To External Forcing Changes, Climatic Change, 13, 191-224, 1988.

Hays, J., Imbrie, J., and Shackleton, N. J..: Variations in the Earth's Orbit: Pacemaker of the Ice Ages, Science, 194, 1121-1132, 1976.

Hibler, W.: Dynamic thermodynamic sea ice model, J. Phys. Oceanogr., 9, 815-846, 1979.

Hurrell, J. W.: Decadal Trends in the North Atlantic Oscillation: Regional Temperatures and Precipitation, Science, 269, 676679, 1995.

Imbrie, J., Boyle, E., Clemens, S., Duffy, A., Howard, W., Kukla, G., Kutzbach, J., Martinson, D., Mcintyre, A., Mix, A., Molfino, B., Morley, J., Peterson, L., Pisias, N., Prell, W., Raytoo, M.,
Shackletons, N., and Toggweiler, J.: On the Structure and origin of major glaciation cycles 1. Linear responses to Milankovich forcing, Paleoceanography, 7(6), 701-738, 1992.

Joussaume, S. and Taylor, K. E.: Status of the Paleoclimate Modeling Intercomparison Project (PMIP), WCRP Report, 425-430, http://pmip.lsce.ipsl.fr/, 1995.

Jungclaus, J. H., Keenlyside, N., Botzet, M., Haak, H., Luo, J. J., Latif, M., Marotzke, J., Mikolajewicz, U., and Roeckner, E.: Ocean circulation and tropical variability in the coupled model ECHAM5/MPI-OM, J. Climate, 19, 3952-3972, 2006.

Kaspar, F., Kuhl, N., Cubasch, U., and Litt, T.: A model-data comparison of European temperatures in the Eemian interglacial, Geophys. Res. Lett., 32, L11703, doi:10.1029/2005GL022456, 2005.

Kaspar, F., Spangehl, T., and Cubasch, U.: Northern hemisphere winter storm tracks of the Eemian interglacial and the last glacial inception, Clim. Past, 3, 181-192, 2007, http://www.clim-past.net/3/181/2007/.

Keith, D.: Meridional energy transport: uncertainty in zonal means, Tellus, 47, 30-44, 1995.

Levitus, S. and Isayev, G.: Polynomial-approximation to the international equation of state for seawater, J. Atmos. Ocean. Tech., 9, 705-708, 1992.

Liu, Z., Brady, E., and Lynch-Stieglitz, J.: Global ocean response to orbital forcing in the Holocene, Paleoceanography, 18(2), 1041, doi:10.1029/2002PA000819, 2003.

Lorenz, S. J., Kim, J., Rimbu, N., Schneider, R. R., and Lohmann, G.: Orbitally driven insolation forcing on Holocene climate trends: Evidence from alkenone data and climate modeling, $\mathrm{Pa}$ leoceanography, 21, doi:10.1029/2005PA001152, 2006.

Marsland, S. J., Haak, H., Jungclaus, J. H., Latif, M., and Roske, F.: The Max-Planck-Institute global ocean/sea ice model with orthogonal curvilinear coordinates, Ocean Modell., 5, 91-127, 2003.

Milankovic, M.: Kanon der Erdbestrahlung und sieine Anwendung auf das Eiszeitenproblem, Special Publication, R. Serb. Acad. Belgrade, 132, 633 pp., 1941.

Otto, J., Raddatz, T., Claussen, M., Brovkin, V., and Gayler, V.: Separation of atmosphere-ocean-vegetation feedbacks and synergies for mid-Holocene climate, Geophys. Res. Lett., 36, L09701, doi:10.1029/2009GL037482, 2009.

Raddatz, T. J., Reick, C. H., Knorr, W., Kattge, J., Roeckner, E., Schnur, R., Schnitzler, K. G., Wetzel, P., and Jungclaus, J.: Will the tropical land biosphere dominate the climate-carbon cycle feedback during the twenty-first century?, Clim. Dynam., 29, 565-574, 2007.

Renssen, H., Goosse, H., and Muscheler, R.: Coupled climate model simulation of Holocene cooling events: oceanic feedback amplifies solar forcing, Clim. Past, 2, 79-90, 2006, http://www.clim-past.net/2/79/2006/.

Rimbu, N., Lohmann, G., Kim, J.-H., Arz, H. W., and Schneider, R.: Arctic/North Atlantic Oscillation signature in Holocene sea surface temperature trends as obtained from alkenone data, Geophys. Res. Lett., 30, 1280, doi:10.1029/2002GL016570, 2003.

Rimbu, N., Lohmann, G., Lorenz, S. J. and, K. J. H., and Schneider, R. R.: Holocene climate variability as derived from alkenone sea surface temperature and coupled ocean-atmosphere model experiments, Clim. Dynam., 23, 215-227, 2004.

Roeckner, E., Bäuml, G., Bonaventura, L., Brokopf, R., Esch, M., 
M., G., Hagemann, S., Kirchner, I., Kornblueh, L., Manzini, E., Rhodin, A., Schlese, U., Schulzweida, U., and Tompkins, A.: The atmospheric general circulation model ECHAM5. Part I: Model description., Tech. Rep. Rep. 349, 127 pp., Max Planck Institute for Meteorology, available from MPI for Meteorology, Bundesstr. 53, 20146 Hamburg, Germany, 2003.

Schurgers, G., Mikolajewicz, U., Groeger, M., Maier-Reimer, E., Vizcaino, M., and Winguth, A.: The effect of land surface changes on Eemian climate, Clim. Dynam., 29, 357-373, doi: 10.1007/s00382-007-0237-x, 2007.

Valcke, S., Caubel, A., Declat, D., and Terray, L.: OASIS Ocean Atmosphere Sea Ice Soil users guide, Tech. rep., CERFACS, 2003.
Wanner, H., Beer, J. Bütikofer, J., Crowley, T., Cubasch, U., Flückiger, J., Goosse, H., Grosjean, M., Joos, F., Kaplan, J., Küttel, M., Müller, S., Prentice, I., Solomina, O., Stocker, T., Tarasov, P., Wagner, M., and Widmann, M.: Mid- to Late Holocene climate change: an overview, Quaternary Sci. Rev., 27, 1791-1828, 2008.

Zhao, Y., Braconnot, P., Marti, O., Harrison, S., Hewitt, C., Kitoh, A.and Liu, Z., Mikolajewicz, U., Otto-Bliesner, B., and Weber, S.: A multi-model analysis of the role of the ocean on the African and Indian monsoon during the mid-Holocene, Clim. Dynam., 25(7-8), 777-800, 2005. 